\title{
Pengabdian Kepada Masyarakat Pelayanan Konseling Individu dan Kelompok pada Warga Binaan di Lembaga Pemasyarakatan Wanita Tangerang
}

\author{
Radhiya Bustan ${ }^{1}$, Emmalia Sutiasasmitha ${ }^{2}$ \\ ${ }^{1}$ Program Studi Psikologi, Fakultas Psikologi dan Pendidikan, Universitas Al Azhar Indonesia, \\ Jl.Sisingamangaraja, Kompleks Masjid Agung Al Azhar Indoneisa, Kebayoran Baru,Jakarta 12110 \\ ${ }^{2}$ Program Studi Bimbingan Penyuluhan Islam, Fakultas Psikologi dan Pendidikan, Universitas Al Azhar \\ Indonesia, Jl.Sisingamangaraja, Kompleks Masjid Agung Al Azhar Indoneisa, Kebayoran Baru,Jakarta 12110
}

Penulis untuk Korespondensi/E-mail: radhiya_bustan@yahoo.com

Abstrak - Dewasa ini permasalahan pidana pada narapidana wanita terus meningkat jumlahnya. Lembaga pemasyarakatan (Lapas) Wanita Tangerang merupakan salah satu usaha pembinaan bagi para wanita yang memiliki masalah hukum pidana. Namun, kehadiran lapas tidak serta merta dapat mereduksi masalah yang terjadi sebelumnya. Malah seringkali ditemukan masalah baru, seperti ketakutan tidak diterima masyarakat, stress karena tidak mampu menyesuaikan diri dengan kehidupan di dalam lapas, kerinduan terhadap keluarga, kekhawatiran akan karir dan pekerjaan setelah keluar dari lapas, demotivasi, trauma akan kasus yang menimpa, dan lain sebagainya. Untuk mengatasi berbagai masalah tersebut, maka diperlukan pelayanan konseling bagi warga binaan. Konseling merupakan salah satu teknik dalam pelayanan bimbingan dan merupakan alat yang penting dari usaha pelayanan konseling bagi warga binaan, yang mana akan terjadi serangkaian hubungan langsung dengan warga binaan, yang bertujuan membantunya untuk mengubah sikap dan tingkah lakunya dalam kelangsungan kehidupan selanjutnya. Metode pelayanan konseling yang dilakukan di Lapas Wanita Tanggerang ini, dilakukan dengan dua cara. Pertama, Konseling Individual adalah pemberian proses bantuan perorangan, yang dilakukan melalui wawancara oleh seorang konselor kepada individu. Kegiatan konseling individu dilakukan melalui pendekatan konseling Eksistential Humanistik, Kognitif Behavior dan Transaksional. Kedua, konseling kelompok adalah layanan konseling yang diselenggarakan dalam suasana kelompok yang memanfaatkan dinamika kelompok, serta terdapat hubungan konseling yang hangat, terbuka, permisif dan penuh keakraban. Kegitan konseling di Lembaga Pemasyarakatan Wanita Tangerang ini dapat membantu mengentaskan masalah yang dialami oleh sebagian warga binaan. Dengan demikian, Lembaga Pemasyarakatan Wanita Tangerang perlu terus menjalin kerjasama dengan pihak-pihak penyedia layanan konseling dengan memfasilitasi sarana dan prasarana yang diperlukan, sehingga pelayanan dapat dilakukan secara berkesinambungan dan terarah. Diperlukan pula dukungan sarana dan prasarana agar pelayanan konseling dapat terlaksana secara optimal.

Abstract - Nowadays, criminal matters in women prisoners keep increase in number. Tangerang Women Prison (Lembaga pemasyrakatan Wanita Tangerang) is one of the solution to nuture women in criminal law issues. However, the existence of this institution does not guarantee reduction to the problematic matters. Often found in prisons there are acts of abuse that ultimately lead to new problematic matters, thus harming not only for her but also for her surroundings. To overcome these problems, counseling services are necessary for the assisted citizens. Counseling is one of the techniques use in guidance services and is one of the important tool in counseling services for the assisted citizens, which will occur a series of direct relationships with the targeted citizens, with the intention to help them improve their attitude and behavior in the next life (after they got released). The counseling services in the Tangerang Women Prison use two methods. The first one, individual counseling is a personal guidance which is done through interviews by a counselor to the individual. Individual counseling activities are conducted through the Existential Humanistic, Behavior Cognitive and 
Transactional approach. The second one, group counseling is a form of counseling services organized in a group atmosphere utilizing group dynamics, as well as a warm, open, permissive and intimate counseling relationship. The activites in the Tangerang Woman Prison should be able to help annihilate the problems experienced by some of the assisted citizens. Therefore, this Institution must establish cooperation with the providers of counseling services by supporting them with the neccesary facilities and infrastructure, so the services can be optimally implemented.

Keywords - Prison, Individual Counseling, Group Counseling

\section{PENDAHULUAN}

\section{Latar Belakang}

$\mathrm{D}$ alam perjalanan hidup manusia, masalah merupakan hal yang pasti ditemui, baik besar ataupun kecil. Dampak dari masalah tersebut dapat berakibat positif ataupun negatif tergantung bagaimana seorang individu menyikapi masalahnya serta bagaimana pengelolaannya. Dalam teori manajemen konflik menurut Nardjana (1994) konflik adalah situasi dimana keinginan atau kehendak yang berbeda atau berlawanan antara satu dengan yang lain, sehingga salah satu atau keduanya saling terganggu. Sedangkan menurut Killman dan Thomas (1978), konflik merupakan kondisi terjadinya ketidakcocokan antar nilai atau tujuan-tujuan yang ingin dicapai, baik yang ada dalam diri individu maupun dalam hubungannya dengan orang lain. Konflik atau masalah inilah yang dianggap sebagai salah satu dinamika yang tidak dapat dihindari dan akan menghasilkan perkembangan yang positif (kemajuan) baik bagi individu ataupun kelompok jika dapat disikapi dan dikelola dengan baik.

Munculnya berbagai masalah kemanusiaan khususnya di kalangan wanita, dari mulai kasus pidana sampai non pidana, menuntut berbagai pihak untuk turut andil dalam menjadi bagian dari solusi permasalahannya. Wanita yang seringkali didengungkan sebagai tiang negara, memiliki peranan yang sangat besar dalam kehidupan berbangsa dan bernegara. Dalam kacamata Islam, wanita khususnya yang berstatus sebagai Ibu, memiliki kedudukan sebagai pendidik pertama di keluarganya, "Al-Umm Madrasatul uula". Sehingga, kesejahteraan peran wanita perlu dijaga keberlangsungannya.

Adanya lembaga pemasyarakatan (Lapas) wanita, merupakan bagian dari ikhtiar pembinaan bagi para wanita yang secara hukum memiliki masalah. Namun, kehadiran lapas wanita yang dimaksudkan sebagai sarana pembinaan ini, tidak serta merta langsung dapat mereduksi masalah yang terjadi sebelumnya. Malah seringkali ditemukan masalah baru, seperti menyukai sesama jenis, pertengkaran verbal maupun fisik, sulit menyesuaikan diri, putus asa, dan lain sebagainya yang dapat merugikan bukan hanya bagi dirinya tetapi juga bagi lingkungan sekitarnya. Contoh kecil misalnya, di dalam lapas wanita ada kasus psikoseksual yang menyukai sesama jenis. Hal ini, salah satunya disebabkan kebutuhan seksual warga binaan lapas wanita yang tidak tersalurkan, ditambah kurangnya faktor moral - spiritual yang mengendalikan hawa nafsu mereka. Selain itu, tekanan atas berbagai permasalahan yang melatarbelakangi para penghuni lapas ini, membuat mereka kehilangan semangat hidup, pesimis dalam menatap masa depan, serta keengganan untuk berbuat positif, sebab menganggap dirinya terlanjur menjadi orang yang bermasalah. Kemudian, sulitnya penyesuaian diri di dalam kehidupan lapas, jarang bertemu keluarga atau bahkan ada yang tidak pernah dikunjungi sama sekali, membuat tekanan psikologis terjadi pada warga binaan di lapas ini. Akhirnya, fenomenafenomena semacam ini jika tidak ditanggulangi dengan baik akan terus menjamur dan memandulkan peran dan fungsi dari lembaga pemasyarakatan. Oleh karenanya dalam optimalisasi pembinaan, Lapas perlu bekerjasama dengan unsur atau bagian lain yang secara khusus mampu membantu meningkatkan pengaruh positif serta dapat membangun motivasi moral - spiritual warga binaan lapas.

Dalam hal ini, peran seorang konselor merupakan salah satu unsur yang sangat diperlukan guna memenuhi harapan di atas. Aktifitas konseling bagi individu-individu yang memiliki masalah merupakan treatment yang tepat dalam memulihkan eksistensi dirinya.

Konseling merupakan suatu proses antar-pribadi, dimana satu orang dibantu oleh satu orang lainnya untuk meningkatkan pemahaman dan kecakapan menemukan masalahnya (Mortensen, 1964: 301). Menurut Jones (1970: 96) konseling adalah suatu hubungan profesional antara seorang konselor yang 
terlatih dengan klien. Jadi, konseling merupakan pelayanan dalam membantu menyediakan kondisi untuk individu agar dapat memenuhi kebutuhan untuk hidup berarti, mempunyai rasa aman, kebutuhan untuk cinta dan respek, harga diri, dapat membuat keputusan serta aktualisasi diri. Seorang konselor akan memberikan kesediaan untuk mendengarkan riwayat hidup kliennya, apa yang menjadi harapan-harapannya, kegagalan-kegagalan yang dialami, emosi-emosi dan tragedi dalam hidupnya, dan masalah-masalah yang dihadapinya.

Berdasarkan pemikiran di atas, dosen dan mahasiswa/i Program Studi Bimbingan Penyuluhan Islam semester $\mathrm{V}$ Fakultas Psikologi dan Pendidikan, memandang perlu untuk melakukan pengabdian masyarakat dalam bentuk kegiatan dakwah konseling, meliputi konseling individu dan kelompok. Adapun kegiatan ini sebagai usaha dalam membantu menyelesaikan permasalahan warga binaan Lapas, dalam hal ini adalah Lembaga Pemasyarakatan Wanita Tangerang. Kegiatan dakwah konseling diantaranya dilakukan dengan konseling individu, konseling kelompok, serta pemberian wawasan agama dan pengetahuan yang mendalam agar para warga binaan dapat menjalani hari-hari mereka dengan lebih optimis, religius dan sehat secara psikologis. Karena itu kegiatan Pengabdian kepada Masyarakat ini mengambil tema "Pelayanan Konseling Individu dan Kelompok pada Warga Binaan di Lembaga Pemasyarakatan Wanita Tangerang".

\section{Tujuan}

Pelayanan dakwah konseling ini secara umum bertujuan untuk memberikan wawasan pada warga binaan di Lembaga Pemasyarakatan Wanita Tangerang, mengenai:

1. Konsep kehidupan yang lebih bermakna dan mendapatkan keberkahan dunia akhirat.

2. Dapat memahami makna kehidupan yang lebih berarti dengan tetap berada di jalan yang sesuai dengan tuntunan Al Qur'an dan Hadits.

3. Pemahaman yang lebih mendalam terhadap agama agar segala aktivitasnya dapat dilandasi sesuai dengan syari'at-syari'at Islam.

4. Mempersiapkan warga binaan secara psikologis agar mampu bersosialisasi dengan masyarakat ketika keluar dari Lapas.

5. Memberikan keterampilan sebagai usaha pemberdayaan bagi warga binaan dalam mengoptimalkan potensi diri.

\section{Rumusan Masalah}

Berdasarkan hasil survei awal, diantara masalah yang dapat dirumuskan diantaranya :

1. Apa saja permasalahan yang dihadapi oleh Warga Binaan Lapas Wanita Tangerang ?

2. Bagaimana gambaran efektivitas pelayanan konseling individu dan kelompok dalam membantu menyelesaikan masalah yang dihadapi Warga Binaan Lapas Wanita Tangerang?

\section{Ruang Lingkup}

Kegiatan pengabdian masyarakat ini dilakukan di Lembaga Pemasyarakatan (Lapas) Wanita Kelas IIA Tangerang, berupa kegiatan dakwah konseling, baik dalam bentuk konseling individu maupun kelompok yang diberikan pada 11 orang Warga Binaan yang ditentukan oleh petugas berdasarkan tingkat kebutuhan mereka dalam menerima pelayanan konseling.

\section{Kontribusi}

Pelayanan konseling pada warga binaan di Lapas Wanita Tangerang, selain membantu untuk memecahkan masalah-masalah yang dihadapi dalam kehidupan di lembaga pemasyarakatan, juga berguna meningkatkan pemahaman agama, motivasi dan pengetahuan baru yang berguna bagi mereka sebagai bekal ketika keluar dari Lapas nantinya. Pelayanan konseling ini juga berguna untuk meningkatkan rasa percaya diri dan memberikan wawasan bahwa hidup adalah usaha dan bekerja dengan tidak melanggar aturan dan norma yang berlaku.

\section{TINJAUAN PUSTAKA}

\section{Pengertian Konseling}

Bimbingan dan konseling merupakan suatu proses yang integral, istilahnya selalu dirangkaikan sehingga menghasilkan pengertian lebih utuh. ${ }^{1}$ Konseling merupakan salah satu teknik dalam pelayanan bimbingan di antara beberapa teknik lainnya, namun konseling sebagaimana dikatakan oleh Schmuller adalah "the heart of guidance program" (Dewa Ketut Sukarni; 1984: 11). Selanjutnya dikatakan pula Ruth Strang (1958) bahwa "Guidance is breader; counseling is a most importance tool of guidance”. Bimbingan itu lebih luas, dan konseling merupakan alat yang paling penting dari usaha pelayanan bimbingan.

\footnotetext{
${ }^{1}$ Hallen, Bimbingan Dan Konseling. Jakarta : Ciputat
} Pers, hlm. 10 
Sedangkan Rogers (1942) mengemukakan "Counseling is a series of direct contacts with the individual which aims to offer him assistance in changing his attitude and behavior", konseling adalah serangkaian hubungan langsung dengan individu yang bertujuan untuk membantu dia (manusia) dalam mengubah sikap dan tingkah lakunya. Adapun, beberapa karakteristik yang terkandung dalam pengertian konseling sebagaimana yang dikutipkan oleh Shertzer dan Stone dalam bukunya Fundamental of Counseling (1976: 173-174) dari Petterson:

1. Konseling ialah berhubungan dengan usaha untuk mempengaruhi perubahan sebagian besar tingkah laku klien secara sukarela (klien ingin untuk mengubah dan mendapatkan bantuan dari konselor)

2. Maksud dari konseling ialah menyajikan kondisi yang dapat memperlancar dan mempermudah perubahan sukarela itu (kondisi-kondisi yang demikian itu adalah merupakan kewajiban individu dalam menentukan pilihan yang tepat untuk berdiri sendiri dan memperoleh kepercayaan diri sendiri)

3. Klien mempunyai batas gerak sesuai dengan tujuan konseling yang secara khusus ditetapkan bersama oleh konselor dan klien pada waktu permulaan proses konseling itu (batas gerak itu ditentukan oleh tujuan konseling, yang sebaliknya ditentukan oleh nilai-nilai dan filsafat yang dianut oleh konselor).

4. Kondisi yang memperlancar perubahan tingkah laku itu diselenggarakan melalui wawancara (tidak semua wawancara adalah konseling, tetapi konseling selalu menyangkut wawancara)

5. Suasana mendengar dalam konseling, tetapi tidak semua proses konseling itu terdiri dari mendengar itu saja

6. Konseling memahami klien.

7. Konseling diselenggarakan dalam suasana probadi dan hasilnya dirahasiakan.

8. Klien mempunyai masalah-masalah psikologis dan konselor memiliki keterampilan atau keahlian dalam membantu memecahkan masalah-masalah psikologis yang dihadapi klien. $^{2}$

Tujuan konseling menurut Adler adalah mengurangi intensitas perasaan rasa rendah diri (inferior), memperbaiki kebiasaan-kebiasaan yang

${ }^{2}$ Ibid., hlm. 12 salah dalam persepsi, menetapkan tujuan hidup, mengembangkan kasih sayang terhadap orang lain, dan meningkatkan kegiatan.

Menurut Ansbacher \& Anbacher (Shertzer \& Stone, 1980, 204) ada tiga komponen pokok dalam proses konseling :

1. Memperoleh pemahaman gaya hidup klien yang spesifik, gejala dan masalahnya, melalui empati, intuisi dan penaksiran konselor. Dalam unsur ini konselor membentuk hipotesis mengenai gaya hidup dan situasi klien.

2. Proses menjelaskan kepada klien, dalam komponen ini hipotesis gaya hidup yang dikembangkan dalam komponen pertama harus ditafsirkan dan dikomunikasikan dengan klien sehingga dapat diterima. Psikologi individual menekankan pentingnya membantu klien untuk memperoleh tilikan terhadap kondisinya.

3. Proses memperkuat minat sosial, klien dengan menghadapkan mereka, secara seimbang, dan menunjukkan minat dan kepedulian mereka.

\section{Metode Konseling}

Pelayanan konseling dilakukan dengan dua cara, yaitu:

Konseling Individu

Konseling individual yaitu layanan bimbingan dan konseling yang memungkinkan peserta didik atau konseling mendapatkan layanan langsung tatap muka (secara perorangan) dengan guru pembimbing dalam rangka pembahasan pengentasan masalah pribadi yang diderita konseling. ${ }^{3}$ Konseling individual adalah proses pemberian bantuan yang di lakukan melalui wawancara konseling oleh seorang ahli (konselor) kepada individu yang sedang mengalami sesuatu masalah (klien) yang bermuara pada teratasinya masalah yang dihadapi klien. ${ }^{4}$

Konseling individual adalah kunci semua kegiatan bimbingan dan konseling. Karena jika menguasai teknik konseling individual berarti akan mudah menjalankan proses konseling yang lain. Proses konseling individu berpengaruh besar terhadap peningkatan klien karena pada konseling individu, konselor berusaha meningkatkan sikap siswa dengan cara berinteraksi selama jangka waktu tertentu dengan cara bertatap muka secara langsung

${ }^{3}$ Hellen, Bimbingan Dan Konseling (Jakarta, Quantum Teaching, 2005) hal : 84

${ }^{4}$ Prayitno, Erman Amti, Dasar-Dasar Bimbingan Dan Konseling (Jakarta, Rineka Cipta, 1994) hal : 105 
untuk menghasilkan peningkatan pada diri klien, baik cara berpikir, berperasaan, sikap, dan perilaku. ${ }^{5}$ Tujuan umum konseling individu adalah membantu klien menstrukturkan kembali masalahnya dan menyadari life style serta mengurangi penilaian negatif terhadap dirinya sendiri serta perasaan-perasaan inferioritasnya. Kemudian membantu dalam mengoreksi persepsinya terhadap lingkungan, agar klien bisa mengarahkan tingkah laku serta mengembangkan kembali minat sosialnya. ${ }^{6}$

Metode yang digunakan dalam pelayanan konseling adalah:

a. Directive; konseling dengan adanya pengarahan. Metode ini dilakukan jika klien benar-benar dalam kondisi kritis dalam memecahkan masalah yang sedang dihadapinya, tingkat pendidikan yang rendah, kepribadian yang tertutup, serta klien kurang memiliki pengetahuan tentang bagaimana konsep keberagamaan seseorang dalam mengahadapi masalah dan menyelesaikannya berdasarkan syari'at-syari'at Islam..

b. Non-directive: konseling dengan tanpa pengarahan. Metode ini dilakukan jika klien dianggap mampu memecahkan masalahnya sendiri. Tiada orang yang lebih tahu masalah dan cara pemecahannya daripada dirinya sendiri. Konselor hanya memberikan stimuli dengan sikap yang empati, penerimaan tanpa syarat, dan menyatu dengan klien agar klien merasa diterima dan merasa mampu memecahkan masalahnya sendiri.

\section{$\underline{\text { Konseling Kelompok }}$}

\section{Pengertian Konseling Kelompok}

Menurut Prayitno (2004) layanan konseling kelompok pada dasarnya adalah layanan konseling perorangan yang dilaksanakan didalam suasana kelompok. Disana ada konselor dan ada klien, yaitu para anggota kelompok (yang jumlahnya minimal dua orang). Disana terjadi hubungan konseling dalam suasana yang diusahakan sama seperti dalam konseling perorangan yaitu hangat, permisif,

5 Holipah, The Using Of Individual Counseling Service to Improve Student's Learning Atitude And Habit At The Second Grade Student of SMP PGRI 6 Bandar Lampung (Journal Counseling, 2011)

${ }^{6}$ Prayitno, Konseling Perorangan (Padang, Universitas Negeri Padang, 2005) hal : 52 terbuka dan penuh keakraban. Dimana juga ada pengungkapan dan pemahaman masalah klien, penelusuran sebab-sebab timbulnya masalah, upaya pemecahan masalah (jika perlu dengan menerapkan metode-metode khusus), kegiatan evaluasi dan tindak lanjut.

Menurut Dewa Ketut Sukardi (2003) konseling kelompok merupakan konseling yang di selenggarakan dalam kelompok, dengan memanfaatkan dinamika kelompok yang terjadi di dalam kelompok itu. Masalah-masalah yang dibahas merupakan masalah perorangan yang muncul di dalam kelompok itu, yang meliputi berbagai masalah dalam segenap bidang bimbingan (bidang bimbingan pribadi, sosial, belajar dan karir).

Menurut Winkel (2007) konseling kelompok adalah suatu proses antar pribadi yang dinamis, yang terpusat pada pemikiran dan perilaku yang disadari. Menurut Gazda (1989) dalam Tatik Romlah (2001) konseling kelompok adalah suatu proses antar pribadi yang dinamis yang memusatkan diri pada pikiran dan perilaku yang sadar dan melibatkan fungsi-fungsi seperti sikap permisif, orientasi pada kenyataan, katarsis, saling pengertian, saling menerima dan membantu. Menurut Tatik Romlah (2001) konseling kelompok adalah upaya untuk membantu individu agar dapat menjalani perkembangannya dengan lebih lancar, upaya itu bersifat pencegahan serta perbaikan agar individu yang bersangkutan dapat menjalani perkembangannya dengan lebih mudah.

Dari uraian-uraian yang disampaikan beberapa ahli di atas maka dapat disimpulkan bahwasanya konseling kelompok merupakan salah satu layanan konseling yang diselenggarakan dalam suasana kelompok yang memanfaatkan dinamika kelompok, serta terdapat hubungan konseling yang hangat, terbuka, permisif dan penuh keakraban. Hal ini merupakan upaya individu untuk membantu individu agar dapat menjalani perkembangannya dengan lebih lancar, upaya itu bersifat preventif dan perbaikan. Sebab, pada konseling kelompok juga ada pengungkapan dan pemahaman masalah klien, penelusuran sebab-sebab timbulnya masalah, upaya pemecahan masalah, kegiatan evaluasi dan tindak lanjut.

\section{Tujuan Konseling Kelompok}

Menurut Dewa Ketut Sukardi, (2002:49).Tujuan konseling kelompok meliputi: 
1) Melatih anggota kelompok agar berani berbicara dengan orang banyak

2) Melatih anggota kelompok dapat bertenggang rasa terhadap teman sebayanya

3) Dapat mengembangkan bakat dan minat masing-masing anggota kelompok

4) Mengentaskan permasalahan - permasalahan kelompok.

Menurut Mungin Eddy Wibowo, (2005:20). Tujuan yang ingin dicapai dalam konseling kelompok, yaitu pengembangan pribadi, pembahasan dan pemecahan masalah pribadi yang dialami oleh masing-masing anggota kelompok, agar terhindar dari masalah dan masalah terselesaikan dengan cepat melalui bantuan anggota kelompok yang lain.

\section{Bentuk-bentuk Konseling Kelompok}

- Wawancara: proses tanya jawab antar anggota kelompok mengenai topik tertentu. Ini dilakukan di awal konseling kelompok agar anggota kelompok dapat saling mengenal, baik sesama mereka maupun dengan dosen dan mahasiswa/i yang akan memberikan konseling kepada mereka.

- Diskusi kelompok: dipandu oleh salah seorang mahasiswa sebagai pemimpin kelompok, dan mahasiswa lainnya sebagai observer.

- Brainstorming: mendiskusikan cara-cara pemecahan satu masalah.

- Buzz session: diskusi informal tentang topik tertentu yang muncul secara spontan, dipandu pemimpin kelompok.

- Kelompok aktivitas: aktivitas informal seperti seni dan keterampilan. Anggota kelompok diajarkan untuk dapat menggali kreativitas dan mengasah potensi yang dimiliki.

\section{Pendekatan Konseling}

\section{Eksistensial Humanistik}

Merupakan terapi experiential, dimana klien harus mau dan mampu mengalami sendiri proses perubahan pada dirinya. Perkembangan kepribadian didasarkan pada keunikan tiap individu. Penekanan pendekatan ini adalah pada masa kini dan masa mendatang, tidak mementingkan peristiwaperistiwa masa lalu. Tujuan konseling berdasarkan pendekatan eksistensial ini adalah untuk membantu klien menyadari bahwa mereka memiliki kebebasan memilih dan bertanggungjawab atas apa yang terjadi pada mereka serta mengidentifikasi faktorfaktor yang menghambat kebebasan mereka. Berdasarkan pendekatan ini, sesuai dengan konsep Islam, konselor akan mengajak klien untuk mau dan berusaha merubah nasib mereka dan terus memotivasi diri dan keluarga untuk membuat perubahan, sejalan dengan firman Allah SWT dalam surat Ar-Ra'd ayat 11 yang artinya bahwa: "Sesungguhnya Allah tidak akan mengubah keadaan suatu kaum sebelum mereka mengubah keadaan diri mereka sendiri".

\section{$\underline{\text { Kognitif Behavior }}$}

Pendekatan ini muncul dari kritik dan keterbatasan terhadap terapi behavior yang hanya merubah perilaku tetapi tidak merubah perasaan, tidak memfasilitasi munculnya insight, dan menolak sejarah yang menyebabkan perilaku.

Asumsi dasar dari pendekatan ini adalah bahwa kognisi, emosi, perilaku berinteraksi secara bermakna dan ada hubungan sebab akibat yang timbal balik. Pendekatan kognitif behavior ini juga menekankan pada cara berpikir, menilai, memutuskan, menganalisa dan melakukan sesuatu.

Manusia cenderung memiliki pemikiran yang salah yang mengarah pada gangguan emosi dan tingkah laku. Kognisi merupakan penentu utama dari bagaimana kita merasakan dan beraksi terhadap sesuatu.

Terapi kognitif behavior merupakan proses belajar, termasuk membentuk dan mempraktekkan keterampilan baru, belajar cara-cara baru dalam berpikir. Walaupun masalah psikologis dapat bersumber pada masa kanak-kanak, tetapi diperburuk oleh reindoktrinasi pada masa sekarang. Keyakinan seseorang merupakan penyebab utama suatu gangguan.

Dialog internal memegang peranan penting dalam tingkah laku seseorang. Mengkonfrontasi keyakinan-keyakinan klien yang salah berdasarkan kenyataan kontradiksi yang diperoleh klien, membantu klien menemukan dan mengurangi keyakinan dogmatisnya, menjadikan klien sadar akan pikiran-pikiran irasional dan mengubahnya dapat digunakan sebagai teknik dalam pendekatan ini (Corey, 2000).

\section{Transaksional}

Pendekatan transaksional analisis ini diperkenalkan oleh Eric Berne, seorang psikiater yang pernah belajar menjadi analis.

Pendekatan ini bertujuan untuk membantu klien membuat keputusan-keputusan baru yang 
berhubungan dengan perilaku dan arah hidupnya saat ini, mendorong klien agar menyadari bahwa kebebasan dirinya dalam memilih telah dibatasi oleh putusan-putusan yang menjadi pilihannya di masa lalu, serta mengganti gaya hidup yang ditandai oleh adanya kesadaran, spontanitas, dan keakraban.

Terapi ini juga membantu klien membebaskan ego orang dewasa dari pencemaran dan pengaruhpengaruh merusak yang dihasilkan oleh ego orang tua dan ego anak. Mengajarkan klien untuk mengenali, menyadari, dan menjabarkan ketiga ego, selama ego tersebut muncul dalam transaksi kelompok. Membantu klien untuk bisa berfikir lebih realistik, dan mencari alternatif-alternatif guna menjalani kehidupan yang lebih otonom.

Fungsi dan peran konselor dalam pendekatan ini adalah untuk menerangkan teknik analisis struktural, analisis transaksional, dan analisis permainan, membantu klien menemukan kondisi yang tidak menguntungkan, adaptasi rencana hidup dan strategi berhubungan dengan orang lain, serta menemukan alternatif hidup yang lebih mandiri.

\section{SOSIALISASI DAN PROFIL RESPONDEN}

\section{Sasaran Khalayak}

Kegiatan pengabdian masyarakat ini diberikan pada 11 orang Warga Binaan di Lembaga Pemasyarakatan Wanita Kelas IIA Tangerang. Pemilihan warga binaan berdasarkan rekomendasi dari pihak Lapas, yang mengalami berbagai masalah dalam kehidupan di lapas, baik terkait penyesuaian diri, masalah pribadi, moral/etika, dan lain sebagainya. Kegiatan dilakukan selama 6 kali pertemuan, terdiri dari 2 kali konseling kelompok dan 4 kali konseling individu serta beberapa kegiatan tambahan lainnya, seperti belajar kerajinan tangan, fun cooking, dan nonton bersama yang kemudian digali pemahaman (insight) dari peserta, sehingga meningkatkan semangat dan memberikan pengetahuan baru sebagai bekal bagi warga binaan ketika keluar dari Lembaga Pemasyarakatan nantinya.

\section{Jadwal Pelaksanaan}

Kegiatan ini secara keseluruhan dilakukan selama 6 bulan, yang dimulai pada bulan November 2016 April 2017, dengan tahap-tahap sebagai berikut:
Tahap Persiapan

Kegiatan ini dimulai dengan melakukan wawancara kepada para warga binaan di Lapas wanita Tangerang sebagai studi pendahuluan untuk menganalisa kebutuhan konseling bagi mereka. Persiapan selanjutnya adalah mempersiapkan materi-materi yang berkaitan dengan konseling dan pengetahuan agama dalam penciptaan sumber daya manusia yang lebih bermutu dan membantu mereka untuk keluar dari permasalahan yang sedang dihadapi. Selain itu, pelaksana kegiatan pengabdian masyarakat menghubungi pihak-pihak yang terkait dengan kegiatan ini, mengurus proses surat izin kegiatan dan kemudian melakukan perkenalan dengan individu-individu serta orang-orang terdekat yang akan diberikan pelayanan konseling. Pada tahap ini juga dipersiapkan materi terkait konseling yang berguna untuk pelaksanaan kegiatan nanti.

Secara umum tahap ini terlaksana sesuai dengan rencana dan tidak menemukan kendala berarti karena sudah terdapat perjanjian kerjasama (MoU) anatara Lembaga Pemasyarakatan Wanita Tangerang dengan Fakultas Psikologi dan Pendidikan Universitas Al Azhar Indonesia.

\section{Tahap Pelaksanaan}

Pelaksanaan kegiatan pengabdian masyarakat ini dimulai pada tanggal 23 November 2016 sampai 28 Desember 2016. Konseling dilakukan sesuai dengan tahap-tahap konseling. Disamping itu, konseling pada kegiatan pengabdian masyarakat ini juga menggunakan pendekatan-pendekatan konseling.

Sarana dan prasarana yang dibutuhkan dipersiapkan oleh pihak lapas bersama dengan tim pelaksana pengabdian masyarakat, seperti: ruangan, papan tulis, spidol, LCD Proyektor, In focus, DVD film, peralatan masak, peralatan kerajian tangan, dll. Adapun jadwal pelaksanaan kegiatan pengabdian masyarakat yang sudah dilakukan adalah sebagai berikut:

Tabel 1. Jadwal Pelaksanaan Kegiatan Pengabdian Masyarakat yang Telah Dilakukan

\begin{tabular}{llll}
\hline Hari/Tgl & Waktu & Kegiatan & Tempat \\
\hline 23 & $10.00-$ & Pembukaan & Perpustaka \\
November & 11.00 & & an \\
\cline { 2 - 3 } 2016 & $11.00-$ & Konseling & \\
& 12.00 & Kelompok & \\
\cline { 2 - 4 } & $12.00-$ & Sholat Zuhur & Musholla \\
& 12.30 & Berjamaah & \\
\hline 30 & $10.00-$ & Konseling & Perpustaka \\
\hline
\end{tabular}




\begin{tabular}{|c|c|c|c|}
\hline Hari/Tgl & Waktu & Kegiatan & Tempat \\
\hline \multirow{3}{*}{$\begin{array}{l}\text { November } \\
2016\end{array}$} & 11.00 & Individu & \multirow[t]{2}{*}{ an } \\
\hline & $\begin{array}{l}11.00- \\
12.00\end{array}$ & $\begin{array}{l}\text { Belajar } \\
\text { Kerajinan } \\
\text { Tangan }\end{array}$ & \\
\hline & $\begin{array}{l}12.00- \\
12.30\end{array}$ & $\begin{array}{l}\text { Sholat Zuhur } \\
\text { Berjamaah }\end{array}$ & Musholla \\
\hline \multirow{3}{*}{$\begin{array}{l}7 \\
\text { Desember } \\
2016\end{array}$} & $\begin{array}{l}10.00- \\
11.00\end{array}$ & $\begin{array}{l}\text { Konseling } \\
\text { Individu }\end{array}$ & \multirow[t]{2}{*}{$\begin{array}{l}\text { Perpustaka } \\
\text { an }\end{array}$} \\
\hline & $\begin{array}{l}11.00- \\
12.00\end{array}$ & $\begin{array}{l}\text { Nonton Film } \\
\text { Bersama }\end{array}$ & \\
\hline & $\begin{array}{l}12.00- \\
12.30\end{array}$ & $\begin{array}{l}\text { Sholat Zuhur } \\
\text { Berjamaah }\end{array}$ & Musholla \\
\hline \multirow{3}{*}{$\begin{array}{l}14 \\
\text { Desember } \\
2016\end{array}$} & $\begin{array}{l}10.00- \\
11.00\end{array}$ & $\begin{array}{l}\text { Konseling } \\
\text { Individu }\end{array}$ & \multirow[t]{2}{*}{$\begin{array}{l}\text { Perpustaka } \\
\text { an }\end{array}$} \\
\hline & $\begin{array}{l}11.00- \\
12.00\end{array}$ & $\begin{array}{l}\text { Sosialisasi } \\
\text { Bekam }\end{array}$ & \\
\hline & $\begin{array}{l}12.00- \\
12.30\end{array}$ & $\begin{array}{l}\text { Sholat Zuhur } \\
\text { Berjamaah }\end{array}$ & Musholla \\
\hline \multirow{3}{*}{$\begin{array}{l}21 \\
\text { Desember } \\
2016\end{array}$} & $\begin{array}{l}10.00- \\
11.00\end{array}$ & $\begin{array}{l}\text { Konseling } \\
\text { Individu }\end{array}$ & \multirow[t]{2}{*}{$\begin{array}{l}\text { Perpustaka } \\
\text { an }\end{array}$} \\
\hline & $\begin{array}{l}11.00- \\
12.00\end{array}$ & Fun Cooking & \\
\hline & $\begin{array}{l}12.00- \\
12.30\end{array}$ & $\begin{array}{l}\text { Sholat Zuhur } \\
\text { Berjamaah }\end{array}$ & Musholla \\
\hline \multirow{3}{*}{$\begin{array}{l}28 \\
\text { Desember } \\
2016\end{array}$} & $\begin{array}{l}10.00- \\
11.00\end{array}$ & $\begin{array}{l}\text { Konseling } \\
\text { Kelompok }\end{array}$ & \multirow[t]{2}{*}{$\begin{array}{l}\text { Perpustaka } \\
\text { an }\end{array}$} \\
\hline & $\begin{array}{l}11.00- \\
12.00\end{array}$ & Penutupan & \\
\hline & $\begin{array}{l}12.00- \\
12.30 \\
\end{array}$ & $\begin{array}{l}\text { Sholat Zuhur } \\
\text { Berjamaah }\end{array}$ & Musholla \\
\hline
\end{tabular}

\section{Tahap Pelaporan}

Langkah terakhir yang dilakukan adalah membuat laporan dari keseluruhan kegiatan pengabdian masyarakat "Pelayanan Konseling Individu dan Kelompok Pada Warga Binaan Di Lembaga Pemasyrakatan Wanita Tangerang" yang telah dilakukan. Disamping itu, akan dilakukan juga evaluasi terhadap kegiatan dengan memberikan pertanyaan mengenai tanggapan peserta mengenai kegiatan yang telah diberikan tersebut.

\section{HASIL DAN PEMBAHASAN}

\section{Gambaran Umum Lapas Wanita Tangerang}

Lembaga Permasyarakatan (Lapas) Kelas IIA Wanita Tangerang didirikan pada tahun 1977 dan difungsikan pada tanggal 5 Februari 1981, merupakan pindahan dari LPW Bukit Duri. Lapas Wanita Tangerang mempunyai tugas untuk melaksanakan pembinaan narapidana wanita (warga binaan) dengan segala kegiatan yang positif dan bermanfaat. Lapas tersebut berkapasitas 257 warga binaan, namun saat ini dihuni kurang lebih sebanyak 457 warga binaan. Menurut keterangan yang disampaikan pihak pengelola, hal ini disebabkan karena sebagian besar warga binaan di Lapas menjalani masa tahanan yang cukup lama dengan kasus yang cukup berat, diantaranya pengedar narkoba, pembunuhan, dan korupsi. sehingga terjadi penumpukan warga binaan. Akibatnya kesesakan ini terkadang menimbulkan kondisi yang kurang baik dalam interaksi keseharian warga binaan.

Lapas Wanita Tangerang memiliki petugas yang keseluruhannya berjumlah 110 orang yang terdiri dari 13 orang pejabat struktural, 61 petugas keamanan, dan 26 orang petugas pembinaan dan staff. Kegiatan pembinaan yang dilakukan di dalam Lapas Kelas IIA Wanita Tangerang berupa pendidikan dan pengajaran, baik pendidikan agama maupun pendidikan umum, kursus-kursus keterampilan dan latihan kerja, olahraga dan kesenian

Latar belakang masalah yang ditemukan tentunya sangat beragam, namun sekitar $70 \%$ dari kasus yang dialami oleh para warga binaan ialah terkait dengan kasus penyalahgunaan Narkoba, baik itu sebagai pemakai, pengedar ataupun penyimpanganpenyimpangan lainnya. Barulah setelahnya kasus lain seperti tindak kriminalitas, pembunuhan, penipuan, trafficking, dan pencucian uang. Masingmasing dari mereka dilokalisasi berdasarkan kasus yang menjeratnya, kasus Narkoba tinggal di bloknya tersendiri dan kasus-kasus lainnya di tempatkan di blok umum. Keragaman lainnya dalam hal menganut agama dan kepercayaan masing-masing yang terjalin sangat harmonis dan saling bertoleransi antara satu sama lain, sehingga tercipta kerukunan diantara sesama warga binaan.

\section{Hasil dan Pembahasan Konseling Individu}

Hasil dari perolehan data di lapangan melalui konseling individu pada sebelas orang klien, ditemukan bahwa setiap Warga Binaan Lapas Wanita Tangerang memiliki latar belakang kasus yang sangat beragam, yang menyebabkan ia ditahan. Setelah berada di dalam Lapas pun tidak luput dari masalah baru, seperti ketakutan tidak diterima masyarakat, stress karena tidak mampu menyesuaikan diri dengan kehidupan di dalam lapas, kerinduan terhadap keluarga, kekhawatiran akan karir dan pekerjaan setelah keluar dari lapas, demotivasi, trauma akan kasus yang menimpa, dan lain sebagainya. Kondisi inilah yang menjadi fokus 
pelaksana abdimas untuk membantu menyelesaikan permasalahan warga binaan tersebut. Dalam pelaksanaannya, diaplikasikan teori-teori konseling juga intervensi religius sehingga dapat menjadi bagian dari solusi permasalahan yang sedang dialami oleh Warga Binaan (Klien).

Proses konseling yang dilkaukan di Lapas, menggunakan dua jenis bentuk konseling, yaitu konseling individu dan konseling kelompok.
Keseluruhan prosesnya berlangsung selama 6 pertemuan dengan jarak satu pekan dari pertemuan satu ke pertemuan lainnya.

Dari sebelas klien Warga Binaan yang diberikan pelayanan konseling, kasus rata-rata adalah terkait penyesuaian diri dan tidak dapat menerima atas kenyataan yang menimpa dirinya. Seperti yang terlihat dalam tabel 2 berikut:

Tabel 2. Kasus, Pendekatan Konseling, dan Pendekatan Keagamaan yang digunakan

\begin{tabular}{|c|c|c|c|}
\hline Klien & Masalah & Pendekatan Konseling & Pendekatan Keagamaan \\
\hline $\bar{K}$ & $\begin{array}{l}\text { Ketakutan tidak bisa } \\
\text { diterima di tengah } \\
\text { masyarakat, setelah } \\
\text { keluar dar lapas. }\end{array}$ & $\begin{array}{lr}\text { Analisis } & \text { Transaksional; } \\
\text { adaptasi } & \text { rencana hidup } \\
\text { dan } & \text { strategi } \\
\text { berhubungan } & \text { dengan } \\
\text { orang lain, serta } \\
\text { menemukan alternatif } \\
\text { hidup yang lebih } \\
\text { mandiri. }\end{array}$ & $\begin{array}{l}\text { Q.S Al-Baqarah ayat 216; } \\
\text { Tawakal kepada Allah; } \\
\text { Ikhtiar secara maksimal. }\end{array}$ \\
\hline $\mathrm{S}$ & $\begin{array}{l}\text { Stress; merasa hidup } \\
\text { kacau dan } \\
\text { berantakan, tidak } \\
\text { lagi mudah percaya } \\
\text { kepada teman. }\end{array}$ & $\begin{array}{lr}\text { Kognitif Behavioral; } \\
\text { membentuk } & \text { dan } \\
\text { mempraktekkan } & \\
\text { keterampilan } & \text { baru, } \\
\text { belajar cara-cara } & \text { baru } \\
\text { dalam berpikir } & \\
\end{array}$ & $\begin{array}{l}\text { Q.S Az - Zukhruf : 67; } \\
\text { Sabar ; Hadist tentang } \\
\text { memilih sahabat }\end{array}$ \\
\hline $\mathrm{F}$ & $\begin{array}{l}\text { Tidak mampu } \\
\text { mengontrol diri ; } \\
\text { Tidak ada titik balik } \\
\text { setelah di Lapas }\end{array}$ & $\begin{array}{lr}\text { Kognitif } & \text { Behavioral; } \\
\text { merubah pemikiran } \\
\text { irasional menjadi } \\
\text { rasional sehingga } \\
\text { membentuk perilaku } \\
\text { baru yang lebih adaptif } \\
\text { dan menatap masa } \\
\text { depan lebih baik }\end{array}$ & $\begin{array}{l}\text { Shalat ; } \quad \text { Kisah-kisah } \\
\text { teladan para salafussalih }\end{array}$ \\
\hline $\mathrm{S}$ & Pengembangan karir & $\begin{array}{l}\text { Eksistensal } \\
\text { Humanistik; mengajak } \\
\text { klien untuk berusaha } \\
\text { merubah nasib mereka } \\
\text { dan terus memotovasi } \\
\text { diri untuk membuat } \\
\text { perubahan. meyakinkan } \\
\text { bahwa setiap manusia } \\
\text { mempunyai } \\
\text { kesempatan untuk lebih } \\
\text { baik, kebebasan } \\
\text { memilih dan } \\
\text { bertanggungjawab } \\
\text { terhadap pilihan hidup } \\
\text { yang sudah mereka } \\
\text { buat. }\end{array}$ & $\begin{array}{l}\text { Q.S. Ath - Thalaq ayat } 3 \\
\text { Q.S Ar-Ra'd ayat 11; } \\
\text { "Sesungguhnya Allah } \\
\text { tidak akan mengubah } \\
\text { keadaan suatu kaum } \\
\text { sebelum mereka mengubah } \\
\text { keadaan diri mereka } \\
\text { sendiri". }\end{array}$ \\
\hline
\end{tabular}




\begin{tabular}{|c|c|c|c|}
\hline Klien & Masalah & Pendekatan Konseling & Pendekatan Keagamaan \\
\hline I & $\begin{array}{l}\text { Dendam (kasus } \\
\text { pembunuhan) }\end{array}$ & $\begin{array}{l}\text { Kognitif Behavioral; } \\
\text { membentuk dan } \\
\text { mempraktekkan } \\
\text { keterampilan baru, } \\
\text { belajar cara-cara baru } \\
\text { dalam berpikir dan } \\
\text { membentuk perilaku } \\
\text { baru yang lebih adaptif }\end{array}$ & Taubatan Nasuha \\
\hline $\mathrm{C}$ & $\begin{array}{l}\text { Sulit menerima } \\
\text { kenyataan }\end{array}$ & $\begin{array}{l}\text { Analisis transaksional; } \\
\text { mendorong klien agar } \\
\text { menyadari bahwa } \\
\text { kebebasan dirinya } \\
\text { dalam memilih telah } \\
\text { dibatasi oleh putusan- } \\
\text { putusan yang menjadi } \\
\text { pilihannya di masa lalu, } \\
\text { serta mengganti gaya } \\
\text { hidup yang ditandai } \\
\text { oleh adanya kesadaran, } \\
\text { spontanitas, dan } \\
\text { keakraban yang lebih } \\
\text { positif. }\end{array}$ & \\
\hline
\end{tabular}

\begin{tabular}{|c|c|c|}
\hline $\mathrm{L}$ & $\begin{array}{lr}\text { Penyesalan } & \text { yang } \\
\text { mendalam, tidak } \\
\text { dapat beradaptasi } \\
\text { dengan lingkungan }\end{array}$ & $\begin{array}{l}\text { Kognitif Behavioral; } \text { Q.S Annisa : 29 ; Hadist } \\
\text { membantu klien dan Majmu Al - Fatawa } \\
\text { menemukan cara baru } \\
\text { dalam berpikir, menilai, } \\
\text { memutuskan, } \\
\text { menganalisar dan } \\
\text { melakukan sesuatu. } \\
\text { Klien diminta untuk } \\
\text { mempraktekkan cara- } \\
\text { cara baru yang lebih } \\
\text { adaptif ralam } \\
\text { kehidupan sosial di } \\
\text { lapas. }\end{array}$ \\
\hline
\end{tabular}

\begin{tabular}{rlll}
\hline Sa Stress, sulit & Analisi transaksional; Muroqobatullah ; Majelis \\
menerima keadaan & membantu klien Ta'lim \\
& membuat keputusan- \\
& keputusan baru, dan \\
& menganalisis kondisi \\
& yang tidak \\
& menguntungkan, \\
& adaptasi rencana hidup \\
& dan strategi \\
& berhubungan dengan \\
& orang lain, serta \\
& menemukan alternatif \\
& hidup yang lebih \\
& mandiri.
\end{tabular}

\begin{tabular}{llllll}
\hline M & Khawatir/rindu anak & Analisis transaksional; "Wasta'iinuu & bisshabr \\
\hline
\end{tabular}




\begin{tabular}{|c|c|c|c|}
\hline Klien & Masalah & Pendekatan Konseling & Pendekatan Keagamaan \\
\hline & $\begin{array}{c}\text {; tidak dapat } \\
\text { menerima kenyataan }\end{array}$ & $\begin{array}{l}\text { mendorong klien agar } \\
\text { menyadari bahwa } \\
\text { kebebasan dirinya } \\
\text { dalam memilih telah } \\
\text { dibatasi oleh putusan- } \\
\text { putusan yang menjadi } \\
\text { pilihannya di masa lalu, } \\
\text { serta mengganti gaya } \\
\text { hidup yang ditandai } \\
\text { oleh adanya kesadaran, } \\
\text { spontanitas, dan } \\
\text { keakraban. }\end{array}$ & $\begin{array}{l}\text { washalah wa innahaa } \\
\text { lakabiratun illaa 'alal } \\
\text { khaasyi'iin", }\end{array}$ \\
\hline $\mathrm{La}$ & $\begin{array}{l}\text { Takut bersosialisasi, } \\
\text { minder }\end{array}$ & $\begin{array}{l}\text { Kognitif Behavioral; } \\
\text { membantu klien } \\
\text { menemukan cara baru } \\
\text { dalam berpikir, menilai, } \\
\text { memutuskan, } \\
\text { menganalisa dan } \\
\text { melakukan sesuatu. } \\
\text { Klien diminta untuk } \\
\text { mempraktekkannya } \\
\text { dalam kehidupan sosial } \\
\text { di lapas. }\end{array}$ & \\
\hline W & $\begin{array}{l}\text { Stress, demotivasi, } \\
\text { kurang percaya diri, } \\
\text { traumatis masa lalu }\end{array}$ & $\begin{array}{lr}\text { Kognitif } & \text { Behavioral; } \\
\text { Mengkonfrontasi } \\
\text { keyakinan-keyakinan } \\
\text { klien yang salah } \\
\text { berdasarkan } & \text { kenyataan } \\
\text { kontradiksi } & \text { yang } \\
\text { diperoleh } & \text { klien, } \\
\text { membantu } & \text { klien } \\
\text { menemukan } & \text { dan } \\
\text { mengurangi } & \text { keyakinan } \\
\text { negatifnya, menjadikan } \\
\text { klien sadar r akan } \\
\text { pikiran-pikiran r } \\
\text { irasional } \\
\text { mengubahnya } \\
\text { rasional menjadi }\end{array}$ & $\begin{array}{l}\text { Q.S Ar - Ra'du ayat } 11 \text {; } \\
\text { membiasakan pengamalan } \\
\text { agama }\end{array}$ \\
\hline
\end{tabular}

Beberapa kasus berkaitan dengan ketidak mampuan klien dalam menyesuaikan diri di lingkungan barunya, kerap juga menimbulkan masalah baru secara psikis. Ada juga yang mengalami demotivasi, stress, hilangnya rasa percaya diri serta ketakutan tidak diterima lagi di masyarakat. Dari keseluruhan masalah yang dialami klien, pendekatan yang umumnya digunakan adalah teori konseling kognitif behavioral dan analisis transaksional. Teori/pendekatan konseling behavioral ini menekankan pada perubahan aspek perilaku pada individu. Dimana, konseling behavioral merupakan salah satu teknik konseling yang menggabungkan dari berbagai teknik dan prosedur konseling. Konseling ini menyertakan penerapan yang sistematis, prinsip-prinsip belajar kepada perubahan tingkah laku ke arah yang lebih adaptif. $^{\text {? }}$

7 Gerald Corey. Teori dan Praktek Konseling dan Psikoterapi. (Bandung: PT Refika Aditama, 2003). Hal. 321 
Dalam konseling behavioral, gejala-gejala yang dilihat adalah merupakan hasil dari pembelajaran, bukan dari hal tak sadar. Konseling ini memusatkan pada dua hal utama, yakni tingkah laku yang tampak sebagai sesuatu yang dapat diamati dan diukur, serta penerapan pola $\mathrm{ABC}$ (Antesendets, Behavior, Concequences) pada tingkah laku melalui penerapan teknik pembelajaran sosial, seperti modeling, pengkondisian klasikal, dan opreant. Klien mampu mengubah tingkah laku yang tidak diinginkan dengan mempelajari tingkah laku baru yang lebih sesuai.

Pada pendekatan analisis transaksional yang diberikan pada 4 orang klien yang pada umumnya mengalami masalah karena tidak mampu menerima kenyataan. Pendekatan ini bertujuan untuk membantu klien membuat keputusan-keputusan baru yang berhubungan dengan perilaku dan arah hidupnya saat ini, mendorong klien agar menyadari bahwa kebebasan dirinya dalam memilih telah dibatasi oleh putusan-putusan yang menjadi pilihannya di masa lalu, serta mengganti gaya hidup yang ditandai oleh adanya kesadaran, spontanitas, dan keakraban yang lebih efektif pada kehidupannya.

Hasil daripada pengguna teori ini, menunjukan pengaruh yang cukup signifikan. Ada perubahan baik yang dialami klien setelah menjalani proses konseling. Adapun pendekatan lain yang digunakan, yaitu pendekatan Eksistensial Humanistik. Satu kasus menggunakan pendekatan ini yang berkaitan dengan pengembangan diri dan karir. Pendekatan ini merupakan terapi experiential, dimana klien harus mau dan mampu mengalami sendiri proses perubahan pada dirinya. Penekanan pendekatan ini adalah pada masa kini dan masa mendatang, tidak mementingkan peristiwaperistiwa masa lalu. Tujuan konseling berdasarkan pendekatan eksistensial ini adalah untuk membantu klien menyadari bahwa mereka memiliki kebebasan memilih dan bertanggungjawab atas apa yang terjadi pada mereka serta mengidentifikasi faktorfaktor yang menghambat kebebasan mereka. Dalam hal ini klien ditantang untuk merencanakan apa yang akan dilakukannya pada masa depan terkait pengembangan dirinya dan pekerjaan yang akan dipilih pada masa yang akan datang dengan penuh tanggungjawab.

\section{Hasil dan Pembahasan Konseling Kelompok}

Kegiatan konseling kelompok dilaksanakan sesuai waktu dan tempat yang telah ditentukan, yaitu dua kali pertemuan pada hari Rabu pada tanggal 23
November 2016 dan hari Rabu pada tanggal 27 Desember 2016, jam 09.00-13.00 bertempat di Lembaga Pemasyarakatan Wanita IIA Tangerang yang berlokasi di jalan M Yamin Daan Mogot Jakarta Barat. Kegiatan ini diikuti oleh 11 orang anggota warga binaan yang dibagi menjadi 2 kelompok. Masing-masing kelompok didampingi oleh ketua kelompok sebagai konselor dari dosen dan mahasiswa Program studi Bimbingan Penyuluhan Islam Fakultas Psikologi dan Pendidikan Universitas Al-Azhar Indonesia.

Kegiatan konseling kelompok ini meliputi empat tahap, yaitu:

\section{Tahap I (Tahap pembentukan/Building Raport)}

Pada tahap pertama ini ketua kelompok mengucapkan salam kepada semua anggota warga binaan dan memimpin doa bersama agar kegiatan yang akan dilaksanakan berjalan dengan lancar. Setelah itu kami sebagai konselor memberikan ucapan terima kasih kepada semua anggota kelompok atas kesediaannya mengikuti kegiatan konseling kelompok. Untuk lebih mengakrabkan anggota kelompok, selanjutnya kami mengadakan perkenalan dengan masing-masing anggota. Kemudian konselor menjelaskan tentang pengertian, tujuan, asas-asas, dan cara pelaksanaan konseling kelompok.

Sebagai syarat utama dalam pelaksanaan praktik konseling kelompok, konselor tidak lupa menyampaikan kerahasiaan kepada semua anggota konseling kelompok. Setelah itu, konselor mendiskusikan bersama-sama dengan semua anggota tentang kesepakatan lama waktu dalam menjalankan konseling kelompok.

Tahap II (Tahap peralihan)

Tahap peralihan setelah melihat kondisi semua anggota sudah terlihat mulai akrab dan semangat, yang ditandai dengan tawa canda para anggota. Kemudian konselor menanyakan kepada semua anggota kelompok mengenai kesiapan mereka dalam mengikuti kegiatan konseling kelompok. Setelah anggota mengungkapkan bahwa mereka siap, kami selaku konselor lalu menjelaskan kembali tentang pengertian, tujuan, asas-asas, dan cara pelaksanaan konseling kelompok. Konselor juga menjelaskan tentang batasan masalah yang akan dibahas dalam kegiatan konseling kelompok, yaitu terbatas pada masalah pribadi masing-masing anggota. Kemudian praktikan mencoba mengenali bagaimana suasana para anggota kelompok dengan 
memperhatikan ekspresi wajah tiap-tiap anggota untuk menuju ke tahap berikutnya.

\section{Tahap III (Kegiatan)}

Setelah melihat kesiapan anggota konseling kelompok untuk memasuki tahap kegiatan, konselor segera memasuki tahap kegiatan. Yang pertama dilakukan adalah memberikan kesempatan kepada para anggota kelompok untuk mengungkapkan masalahnya masing-masing. Pada awalnya, para anggota masih diam saja, belum ada yang mau sukarela dan terbuka untuk mengungkapkan masalah pribadinya. Tetapi kemudian ada salah satu anggota yang mau mengawali mengungkapkan masalah pribadinya. Setelah itu dilanjutkan dengan anggota yang lain secara bergantian.

Setelah terungkap beberapa masalah yang dikemukakan oleh masing-masing anggota kelompok, kemudian konselor menawarkan kepada semua anggota kelompok masalah mana yang akan dibahas terlebih dahulu. Berdasarkan atas kesepakatan semua anggota kelompok, akhirnya dipilih masalah yang dialami oleh Ld. Konselor menanyakan kepada anggota kelompok keonseling, apakah mereka setuju bila masalahnya yang akan dibahas dalam kegiatan konseling kelompok kali ini, Ld dan anggota lainnya setuju. Masalah yang dialami oleh Ld adalah masalah mengenai hubungan yang kurang begitu harmonis dengan warga binaan yang lain dalam suatu ruangan. Ld mengaku ia jarang sekali berkomunikasi dengan warga binaan yang lain sehingga hubungannya dengan warga binaan yang lain kurang harmonis.

Setelah Ld menceritakan masalah yang sedang dialaminya, lalu konselor meminta anggota kelompok untuk berpendapat, bertanya, ataupun memberikan saran terhadap solusi masalah yang sedang dialami oleh Ld. Anggota kelompok terlihat antusias untuk membantu Ld menyelesaikan masalahnya, hal ini terlihat dari anggota aktif bertanya lebih dalam tentang masalahnya juga memberikan beberapa alternatif solusi pemecahan masalah untuk Ld. Pada tahapan ini, dinamika antar anggota kelompok sudah mulai terbentuk dan terlihat. Beberapa point alternatif solusi yang ditawarkan oleh anggota diantaranya:

1) Mencoba aktif menjalin komunikasi dengan warga binaan.

2) Mencoba menyapa warga binaan yang lain dengan ramah.
3) Mencoba mengobrol untuk lebih mengakrabkan diri kepada warga biaan yang lain.

Berdasarkan poin-poin solusi tersebut, lalu konselor meminta pendapat $\mathrm{Ld}$ solusi mana yang mungkin bisa dilakukannya. Kemudian, hal terakhir yang dilakukan konselor adalah memberi kesimpulan dari pembahasan masalah yang telah dibahas.

\section{Tahap IV (Tahap pengakhiran)}

Pada tahap pengakhiran, konselor menjelaskan kepada semua anggota kelompok bahwa kegiatan konseling kelompok akan segera diakhiri. Konselor juga menanyakan kepada anggota kelompok tentang harapan-harapan yang mereka miliki terkait dengan kegiatan konseling kelompok. Setelah semua anggota kelompok mengungkapkan harapannya. Tahap ini ditutup dengan perpisahan dengan anggota kelompok dan mengucapkan terima kasih.

\section{Evaluasi}

Di akhir pertemuan konseling, pelaksana pengabdian masyarakat meminta kesan dan pesan dari peserta sebagai bahan evaluasi. Kesan mereka baik terhadap kegiatan konseling ini, mereka mengaku banyak manfaat yang mereka dapatkan selama enam pekan berlangsung. Mereka bisa mengungkapkan apa masalah yang mereka alami selama berada di Lapas yang tidak mampu mereka ceritakan pada siapapun karena rasa kurang percaya satu sama lain. Selain itu, kegiatan pengabdian masyarakat ini memberikan suasana baru bagi warga binaan, karena selama mereka berada di Lapas hanya bertemu dengan orang yang sama. Dengan menceritakan masalah dapat mengurangi beban yang mereka rasakan selama ini. Diantara mereka ada yang mengungkapkannya dengan berurai airmata. Mereka mengucapkan banyak terimakasih pada kami, dan begitu pula sebaliknya kami juga menyampaikan terimakasih atas keterbukaan mereka menerima kehadiran kami.

Selain menyampaikan kesan-kesan terhadap kegiatan konseling yang kami lakukan di Lapas, para warga binaan juga menyampaikan harapan mereka kelak jika sudah keluar dari Lapas dan kembali kepada keluarga mereka. Diantara harapan-harapan yang disampaikan oleh warga binaan Lembaga Pemasyarakatan Wanita Kelas II A Tangerang ialah:

I: "Saya berusaha akan jadi Ibu yang baik untuk anak saya dan kembali menggunakan jilbab. Juga berusaha selalu melaksanakan sholat." 
K: "Saya akan menjalani kehidupan di luar seperti biasa dan selalu melakukan hal-hal yang bermanfaat."

L: "Saya akan menjadi istri yang jauh lebih baik lagi, tidak egois, dan mau mendengarkan suami."

F: "Saya mau berusaha supaya rajin sholat, tidak mengulangi kesalahan dan melakukan hal-hal yang baik."

Evaluasi dari sisi pelaksana kegiatan pengabdian masyarakat adalah dengan melibatkan mahasiswa membuat mahasiswa mendapat pengalaman nyata bagaimana melakukan proses konseling baik individu maupun kelompok. Mahasiswa dapat mempraktikkan langkah-langkah pelaksanaan konseling, mengetahui dan merasakan suasana konseling, pengalaman berbicara didepan kelompok, melatih kepercayaan diri, melatih kepemimpinan, melatih kelancaran berbicara di depan umum, dan dapat menjadi sarana untuk melatih mengontrol emosi.

Selain mengalami beberapa kemajuan, pelaksana abdimas juga masih mempunyai beberapa kelemahan, diantaranya:

1. Masih cenderung terhanyut dengan keadaan ketika pembahasan masalah.

2. Kurang mampu mengarahkan jalannya konseling fokus pada pembahasan masalah.

3. Masih belum sepenuhnya bisa mengontrol anggota kelompok.

4. Masih merasa gugup ketika memberikan layanan konseling.

5. Masih kesulitan dalam menguraikan dan menjelaskan pertanyaan serta mempraktikkan teknik-teknik konseling.

6. Minimnya sarana dan prasarana yang mendukung pelaksanaan konseling, seperti luas ruangan yang kurang memadai, sehingga kurang privasi dan cenderung berisik, suhu ruangan yang cukup panas, serta suasana yang masih kurang kondusif.

\section{KESIMPULAN DAN SARAN}

\section{Kesimpulan}

Berdasarkan kegiatan pengabdian masyarakat yang dilakukan di Lembaga Pemasyarakatan Wanita Kelas II A Tangerang selama 6 minggu dari tanggal 23 November sampai 28 Desember 2016, diperoleh kesimpulan bahwa permasalahan yang sering muncul pada warga binaan adalah terkait penyesuaian diri di lapas maupun kekhawatiran untuk menghadapi kehidupan di luar lapas, kurangnya percaya diri, stress, dan trauma akibat kasus yang dialami. Kegiatan pengabdian masyarakat dilakukan dalam bentuk konseling individu dan kelompok pada 11 orang warga binaan tersebut untuk membantu mencari jalan keluar dari permasalahan yang mereka hadapi. Konseling individu menggunakan pendekatan kognitif behavior, eksistensial humanistik, dan transaksional. Sementara konseling kelompok dilakukan dengan metode diskusi terkait masalah yang dihadapi warga binaan, baik masalah pribadi, sosial, maupun harapan terhadap karir. Proses pelaksanaanya dilakukan melalui 4 tahap yaitu :

1. Pembentukan

2. Peralihan

3. Kegiatan

4. Pengakhiran

Manfaat dari layanan ini adalah membantu mengentaskan masalah yang dialami anggota lapas wanita Tangerang melalui dinamika kelompok.

Selain itu juga diadakan kegiatan nonton bersama yang kemudian digali pemahaman (insight) dari peserta terkait film tersebut. Kegiatan lainnya adalah belajar keterampilan dan fun cooking. Kegiatan-kegiatan ini dapat meningkatkan semangat dan memberikan pengetahuan baru sebagai bekal bagi warga binaan ketika keluar dari Lembaga Pemasyarakatan nantinya.

\section{Saran}

1. Perlu adanya peran konselor dalam menangani permasalahan psikologis warga binaan agar tetap mampu menjalani fungsi-fungsi mereka sebagaimana seharusnya. Dengan demikian, Lembaga Pemasyarakatan Wanita Tangerang perlu menjalin kerjasama dengan pihak-pihak penyedia layanan konseling, sehingga pelayanan dapat dilakukan secara berkesinambungan dan terarah.

2. Lembaga Pemasyarakatan juga diharapkan dapat menyediakan sarana dan prasarana yang mendukung dalam proses pelaksanaan konseling individu maupun kelompok.

3. Warga binaan diharapkan dapat berpartisipasi secara optimal dalam kegiatan-kegiatan yang dilaksanakan di Lembaga Pemasyarakatan agar dapat memberikan manfaat untuk perkembangan fisik, psikologis, maupun spiritualnya. Khususnya untuk pelayanan konseling, diharapkan warga binaan bisa lebih terbuka dalam menyampaikan masalahnya agar dapat menemukan solusi bersama-sama dengan konselor. 
4. Pelaksana kegiatan pengabdian masyarakat diharapkan dapat lebih menguasai materi konseling dan aplikasinya agar mampu memberikan pelayanan secara maksimal. Diperlukan jam terbang untuk melakukan praktek konseling bagi mahasiswa yang terlibat agar lebih menguasai pelaksanaan konseling.

\section{DAFTAR PUSTAKA}

[1] D.K.Sukardi. Pengantar Pelaksanaan Program Bimbingan dan Konseling. Jakarta: Rineka Cipta. 2002.

[2] Erhamwilda. Konseling Islami. Yogyakarta : Graha Ilmu. 2009.

[3] M.E.Wibowo, Konseling Kelompok Perkembangan. Semarang: Unnes Press. 2005.
[4] Hallen. Bimbingan Dan Konseling. Jakarta : Ciputat Pers. 2009.

[5] Holipah, The Using of Individual Counseling Service to Improve Student's Learning Atitude And Habit At The Second Grade Student of SMP PGRI 6 Bandar Lampung (Journal Counseling, 2011).

[6] H.Prayitno dan E.Amti, Dasar-Dasar Bimbingan Dan Konseling, Jakarta : Rineka Cipta,1994.

[7] Prayitno. Layanan Bimbingan dan Konseling. Jakarta: Ghalia Indonesia. 2004.

[8] Romlah. Tatik, Teori dan Praktik Bimbingan Kelompok. Malang: Universitas Negeri Malang, 2001.

[9] D.K. Sukardi, Pengantar Pelaksanaan Program Bimbingan Konseling. Jakarta : Rieneka Cipta. 2008.

[10] W. S. Winkel dan M.M. Sri Hastuti. Bimbingan Dan Konseling Di Institusi Pendidikan. Yogyakarta: Media Abadi. 2004. 